Article

\title{
Economic Assessment of an Integrated Membrane System for Secondary Effluent Polishing for Unrestricted Reuse
}

\author{
Amos Bick ${ }^{1}$, Leonid Gillerman ${ }^{2}$, Yossi $\operatorname{Manor}^{3}$ and Gideon Oron ${ }^{2,4,5, *}$ \\ 1 The Department of Chemical Engineering, Shenkar College of Engineering and Design, \\ Ramat-Gan 52526, Israel; E-Mail: amosbick@walla.com
}

2 The Institutes for Desert Research, Ben-Gurion University of the Negev, Kiryat Sde-Boker 84990, Israel; E-Mail: gillerma@bgu.ac.il

3 Central Virological Lab., Sheba Medical Center, Tel-HaShomer 52621, Israel;

E-Mail: yossi.manor@sheba.health.gov.il

4 The Department of Industrial Engineering and Management and the Environmental Engineering Program, Ben-Gurion University of The Negev, Beer-Sheva 84105, Israel

5 The Department of Industrial Engineering and Management, Jerusalem College of Engineering, Jerusalem 96920, Israel

* Author to whom correspondence should be addressed; E-Mail: gidi@bgu.ac.il; Tel.:+972-7-659-6900; Fax: +972-7-659-6909.

Received: 23 January 2012; in revised form: 17 February 2012 / Accepted: 20 February 2012 / Published: 5 March 2012

\begin{abstract}
Extra treatment stages are required to polish the secondary effluent for unrestricted reuse, primarily for agricultural irrigation. Improved technology for the removal of particles, turbidity, bacteria and cysts, without the use of disinfectants is based on MicroFiltration (MF) and UltraFiltration (UF) membrane technology and in series with Reverse Osmosis (RO) for dissolved solids removal. Field experiments were conducted using a mobile UF and RO membrane pilot unit at a capacity of around $1.0 \mathrm{~m}^{3} / \mathrm{hr}$. A management model was defined and tested towards optimal polishing of secondary effluent. The two major purposes of the management model are: (i) to delineate a methodology for economic assessment of optimal membrane technology implementation for secondary effluent upgrading for unrestricted use, and; (ii) to provide guidelines for optimal RO membrane selection in regards to the pretreatment stage. The defined linear model takes into account the costs of the feed secondary effluent, the UF pretreatment and the RO process. Technological constraints refer primarily to the longevity of the membrane and their performance. Final treatment cost (the objective function) includes investment,
\end{abstract}


operation and maintenance expenses, UF pretreatment, RO treatment, post treatment and incentive for low salinity permeate use. The cost range of water for irrigation according to the model is between 15 and 42 US cents per $\mathrm{m}^{3}$.

Keywords: effluent; membranes; optimization; renovation; reverse-osmosis; management modeling

\section{Introduction}

Spiraling demand for high quality water, coupled with natural shortage, mainly due to intensive exploitation of groundwater from aquifers and continuous deterioration of supplies, primarily in arid zones, has stimulated the search for alternative sources and water treatment methods [1]. The gap between supply and demand can be bridged primarily by implementing two major strategic directions: (i) to import water from external sources, and; (ii) to further develop non-conventional water sources - which under specific conditions allow treating the water to acceptable use levels, primarily for agriculture irrigation [2]. Potential extra water treatment methods, including the use of membrane technology [3], are primarily for saline and seawater upgrading. At first glance, membrane treatment of domestic effluent appears attractive, since effluent is a stable water source. However, the brine disposal is of serious concern due to potential environmental pollution [4].

Effluent treatment has attracted extensive attention [5]. The improved technology for the removal of particles, turbidity, bacteria and cysts [6] without the use of disinfectants is based on the use of membranes, mainly by MicroFiltration (MF) and UltraFiltration (UF). The advantages of MF or UF for organic matter removal, with the selectivity of salt removal by Reverse Osmosis (RO) membranes, combine an integrated system that is very promising $[7,8]$.

UF membranes cover a wide range of Molecular Weight Cutoff (MWCO) and pore sizes. Operational pressures range from 0.5 to 7 bar (7 to 100 psi), depending upon the application. "Tight" UF membranes (MWCO 1,000 to 10,000 Dalton) can be used for the removal of soluble organic matter from surface water. The objective of using "loose" membranes [MWCO $>$ 50,000 Dalton, 0.7 to 2.1 bar (10 to $30 \mathrm{psi}$ ), with a pore size of approximately $0.01 \mu \mathrm{m}$ ] is primarily for the removal of particles and microbial components. A major difference between MF and "loose" UF is the membrane pore size: that of MF is 0.05 to $5 \mu \mathrm{m}$ and is approximately one order of magnitude larger than the UF pores. The application of MF membrane is mainly for particle and pathogens removal [9]. Virus size ranges from 0.02 to $0.08 \mu \mathrm{m}$, followed by bacteria $(0.5$ to $10 \mu \mathrm{m})$ and protozoan cysts and oocysts ( 3 to $15 \mu \mathrm{m}$ ). It is apparent that removal of these organisms is specific to particular membranes and their pore size distribution (considering the membrane as a simple physical barrier). However, other physical, microbial and chemical mechanisms also play an important role in the removal of microorganisms [10].

Reverse Osmosis processes have traditionally been used for the removal of salts from brackish and seawater. The first large reverse osmosis plant to treat wastewater is a part of "Water Factory 21" (WF21) in Orange County, CA, USA. The RO permeate is injected into local aquifers thus preventing seawater intrusion and maintaining relatively high water quality in the aquifer. Orange Country is now 
undertaking the design phase of a major expansion at WF21 so that they can reclaim $336,000 \mathrm{~m}^{3} /$ day by the year 2020 [11]. The results of earlier pilot plant studies at WF21 have led to the operation of a $2,712 \mathrm{~m}^{3} /$ day Continuous MicroFiltration (CMF) and RO plant. This demonstration project has been running since 1994, generates water quality data, allows conducting detailed costs analyses, and refines updated design criteria for full-scale system. The successful results from WF21 encouraged other cities such as Scottsdale (east of Phoenix Arizona), Los Angeles, California [12,13] and Honolulu, Hawaii [11], to develop their sustainable water supplies, based on MF or UF systems as a pretreatment stage for the RO units.

The real issue, particularly for wastewater reclamation, is the integrity of the membrane systems for the removal of pathogens, dissolved solids and various micropollutants. Although the microorganisms should theoretically be removed to below detection limits, there are often cases when high levels of removal are not achieved. Thus, it is critical to ensure that the membranes are intact and continuously provide a barrier between feed wastewater and permeate [14]. There are several different methods that can be employed in order to assess membrane integrity. These include: monitoring of turbidity, particle count and size distribution, total organic matter content, electrical conductivity, air pressure testing and sonic wave sensing [15].

Selecting a specific membrane is based on practical knowledge, the experience of the supplier and the end user and additional data mined from the literature and published experiments. There are various methods for fast, short-term testing of the fouling properties of various membranes, such as: (i) autopsy, (ii) Specific Oxygen Consumption Rate (SOCR), (iii) MFI (Multi Fouling Index)-UF, and; (v) a continuous on-line monitoring with a single spiral wound membrane element. These methods were mainly developed at KIWA and VITO research institutes (The Dutch Institute for Drinking Water Research and The Flemish Institute for Technological Research-Vision of Technology, respectively) [16,17].

In evaluating the removal effectiveness of MF/UF systems, it is very important to consider the level of chemical cleaning in place, back-washing and membrane maintenance. Membrane performance efficiency can be diminished if cleaning processes are not adequate. Pilot studies are therefore critical for understanding and maintaining efficient performance of membrane systems. The U.S. Environmental Protection Agency (EPA) has established programs, called the Environmental Technology Verification (ETV), for solving failures of membrane systems [18]. The EPA and the US National Sanitation Foundation (NSF) have cooperatively prepared a program allowing verification of package water treatment systems for drinking and commercial needs. For microorganisms and the removal of particles, the test plants use mainly MF and UF membranes. For the removal of natural organic matter, synthetic organic chemicals and inorganic chemicals, RO and NanoFiltration (NF) are often utilized. Several membrane models are currently under examination, enabling testing membrane performance efficiencies in pilot plants [18]: Aquasource model A35 (UF), F.B. Leopold model Ultrabar Mark III (UF), Hydranautics model ESPA2-4040 (RO), Hydranautics model HydraCap (UF), Koch model TFC ${ }^{\circledR}$ ULPR (RO), PCI model AFC-30 (NF), Ionics model UF-1-7T (UF), Zenon ZeeWeed ${ }^{\circledR}$ ZW-500 (UF) and Pall model WPM-1 (MF).

It is hypothesized that membrane methods are required for polishing secondary effluent for unrestricted use and maintaining sustainable agriculture production. However, operating membrane systems is subject to fouling phenomena, which require methods of evaluation in order to diminish the 
clogging processes. Pilot plant studies were conducted in the fields of Kibbutz Chafets-Chaim, located $40 \mathrm{~km}$ west of the City of Jerusalem, Israel, in order to evaluate the efficiency of a UF/RO hybrid system for polishing secondary effluent. Besides providing reliable and consistent reclaimed effluent used for agriculture irrigation, the objectives of this study are: (i) to provide sufficient technical information and understand the performance of UF and RO membranes in an integrative secondary effluent polishing system; (ii) to provide a reliable and consistent supply of reclaimed effluent that is suitable for agriculture irrigation; (iii) to generate operating data which confirms the feasibility of the pilot plant to consistently meet irrigation standards for unrestricted reuse; (iv) to evaluate the UF pretreatment process phase and identify the frequency of back-wash; (v) to evaluate the linkage between UF and RO membranes during fouling, and (vi) to provide data to enable an economic analysis to be conducted when applying polished effluent, the impact on the yields and soil salinity.

\section{Methods and Data}

\subsection{Wastewater Reclamation Criteria}

Considering the reuse criteria for domestic reclaimed effluent for irrigation in Israel [19], several major routes can be identified: (i) water has to be disinfected [20]; (ii) the daily average turbidity should not exceed 2 NTUs': 5 NTUs' should not be exceeded at any time during operation, and (iii) total coliform content should be below 2.2 per $100 \mathrm{~mL}$ and a maximum total content in any sample should not exceed 23 per $100 \mathrm{~mL}$. In addition, if disinfection is achieved by means other than a chlorine-based process, then 4 logs reduction in F-specific bacteriophage MS2 must be achieved [21] (Bacteriophage MS2 is a pathogen simulant used instead of pathogenic viruses and is essentially an icosahedral positive-sense single stranded RNA virus that infects the Escherichia coli bacterium). The above criteria refer primarily to health and sanitary aspects. Additional criteria refer to $\mathrm{BOD}_{5}$ and TSS content (5 days Biological Oxygen Demand and Total Suspended Solids, respectively), in secondary effluent, up to $20 \mathrm{mg} / \mathrm{L}$ and $30 \mathrm{mg} / \mathrm{L}$, respectively, and residual chlorine (for disinfection) in the applied effluent (at least $1 \mathrm{mg} / \mathrm{L}$ at end points of the irrigation system).

These standards can be met with traditional treatment and disinfection methods. However, domestic wastewater contains significant amounts of chloride ions. Typical chloride concentration in the supplied domestic tap water in Israel ranges from 250 to $600 \mathrm{mg} / \mathrm{L}$ and it is almost double that figure in raw domestic wastewater [22]. Currently, Israel annually reclaims close to $70 \%$ of treated domestic wastewater out of the approximate fresh water supply of $600 \times 10^{6} \mathrm{~m}^{3}$ per year. Accordingly, the estimated annual salt content in wastewater is around 100,000 ton/year out of 360,000 ton/year which are added to agricultural areas by irrigation [23]. This high chloride ion content generates a major threat to achieving economic agriculture yields and maintaining sustainable production. It is well known that common filtration methods do not remove dissolved chloride ions.

Experts reviewed the existing information and developed practical guidelines for evaluating water quality for irrigation [24] (Table 1). Several different quality parameters are used to classify the suitability of water for irrigation and recommended ranges in reference to the minerals content (Table 2) $[24,25]$. High boron content is frequently associated with plant toxicity, and levels should not exceed those given in Table 3 [24,26]. Commonly, water with an Electrical Conductivity (EC) of less $0.5 \mathrm{dS} / \mathrm{m}$ can be applied as irrigation of most crops. With an EC of up to $1.0 \mathrm{dS} / \mathrm{m}$, water can be 
applied for irrigation of medium tolerant crops. Water with higher EC values needs extra treatment, including optional desalination.

Table 1. Guidelines for interpretation of mineral content in effluent applied for irrigation [24].

\begin{tabular}{llcccc}
\hline \multicolumn{1}{c}{ Potential } & \multirow{2}{*}{ Type } & \multirow{2}{*}{ Units } & \multicolumn{3}{c}{ Degree of restrictions for use } \\
\cline { 1 - 3 } Irrigation problem & & & None & Slight to moderate & Severe \\
\cline { 1 - 3 } Salinity & EC & $\mathrm{dS} / \mathrm{m}$ & $<0.7$ & $0.7-3.0$ & $3.0<$ \\
& $\mathrm{TDS}$ & $\mathrm{mg} / \mathrm{L}$ & $<450$ & $450-2,000$ & $2,000<$ \\
Sodium & Surface irrigation & $\mathrm{SAR}$ & $<0.3$ & $3-9$ & $9<$ \\
& Sprinkler irrigation & $\mathrm{mmol} / \mathrm{L}$ & $<3$ & $3<$ & \\
Chloride & Surface irrigation & $\mathrm{mmol} / \mathrm{L}$ & $<4$ & $4-10$ & $10<$ \\
& Sprinkler irrigation & $\mathrm{mmol} / \mathrm{L}$ & $<3$ & $3<$ & \\
Boron & & $\mathrm{mg} / \mathrm{L}$ & $<0.7 *$ & $0.7-3.0$ & $3.0<$ \\
Nitrogen & & $\mathrm{mg} / \mathrm{L}$ & $<5$ & $5-30$ & $30<$ \\
Bicarbonate & & $\mathrm{mmol} / \mathrm{L}$ & $<1.5$ & $1.5-8.5$ & $8.5<$ \\
$\mathrm{pH}$ & & & & $6.5-8.4$ & \\
\hline
\end{tabular}

* In Israel Boron should be $<0.4 \mathrm{mg} / \mathrm{L}$.

Table 2. Permissible limits for classes of irrigation water [24,25].

\begin{tabular}{cccccc}
\hline Class & $\begin{array}{c}\text { Electric } \\
\text { conductivity } \\
\boldsymbol{\mu m h o s}\end{array}$ & $\begin{array}{c}\text { Total dissolved } \\
\text { solids, } \mathbf{p p m}\end{array}$ & $\begin{array}{c}\text { Sodium } \\
\mathbf{\%}\end{array}$ & $\begin{array}{c}\text { Chloride } \\
\mathbf{m g} / \mathbf{L}\end{array}$ & $\begin{array}{c}\text { Sulfate } \\
\mathbf{m e q} / \mathbf{L}\end{array}$ \\
\hline Class 1, Excellent & 250 & 175 & 20 & 4 & 4 \\
Class 2, Good & $250-750$ & $175-525$ & $20-40$ & $4-7$ & $4-7$ \\
Class 3, Permissible & $750-2,000$ & $525-1,400$ & $40-60$ & $7-12$ & $7-12$ \\
Class 4, Doubtful & $2,000-3,000$ & $1,400-2,100$ & $60-80$ & $12-20$ & $12-20$ \\
Class 5, Unsuitable & 3,000 & 2,100 & 80 & 20 & 20 \\
\hline
\end{tabular}

Table 3. Approximate limits of boron in irrigation water/effluent $[24,26]$.

\begin{tabular}{cccc}
\hline \multirow{2}{*}{ Class } & \multicolumn{3}{c}{ Permissible limits for boron (in ppm) for crop groups } \\
\cline { 2 - 4 } & Sensitive $^{(*)}$ & Semi-tolerant $^{(* *)}$ & Tolerant $^{(* * *)}$ \\
\hline Class 1, Excellent & $<0.33$ & $<0.67$ & $<2.00$ \\
Class 2, Good & $0.33-0.67$ & $0.67-1.0$ & $2.0-4.0$ \\
Class 3, Permissible & $0.67-1.00$ & $1.0-1.25$ & $4.0-6.0$ \\
Class 4, Doubtful & $1.00-1.25$ & $1.25-2.0$ & $6.0<$ \\
\hline
\end{tabular}

(*) Pecan, Walnut, Jerusalem-artichoke, Navy beam, American elm, Plum, Pear, Apple, Grape, Kadota fig, Persimmon, Cherry, Peach, Apricot, Thornless blackberry, Orange, Avocado, Grapefruit, Lemon; (**) Sunflower, Potato Cotton, Tomato, Sweet tea, Radish, Field pea, Ragged robin rose, Olive, Barley, Wheat, Corn, Milo, Oat, Zinnia, Pumpkin, Bell pepper, Sweet potato, Lima bean; (***) Athel, Asparagus, Palm, Sugar beet, Magel, Garden beet, Alfalfa, Gladiolus, Broadbean, Onion, Turnip, Cabbage, Lettuce, Carrot.

It is believed that soon, wastewater treatment levels will be also dictated by the requirements of local recipients and not only by some general regulations [27]. The methods for evaluating the overall 
design and operation of wastewater treatment systems are therefore important for both economic and environmental considerations [28].

Testing pilot reclamation plants are based on the Integrated Membrane System (IMS) approach, and combine UF and RO membranes. The advantages of IMSs' include: (i) brine is recovered in a concentrated liquid form, allowing recycling; (ii) generally, no expendable chemicals are needed; (iii) MF/UF filtrate quality is very good and the colloidal fouling load on the RO is reduced as given by the low Silt Density Index (SDI) and turbidity, and (iv) modular design allows less floor area, can be easily modified, is of high reliability and can be easily expanded. The IMS has several limitations:

(i) potential of membrane fouling due to particulate settling or precipitation of dissolved solids, (ii) the flux of the MF/UF treatment units depends on organic concentration levels, and (iii) there are relatively high initial capital costs.

\subsection{Management Modeling}

Management models provide an effective means of rapidly testing and evaluating different scenarios for a given set of conditions [29]. Well-defined models allow examination of many hypothetical situations, yielding perceptive insights. Although models frequently deviate from real life situations, they provide preferences towards optimal system selection and potential directions of preferable processes [30]. These directions can be consequently interpreted by decision-makers in project evaluation and implementation [31].

The important tasks involved in managing water quality are to perform a cost-effective analysis, create an economic and environmental balance and turn sustainable water use into practice [32]. The integrative approach is based on trying to encompass all relevant aspects of the membrane units under consideration. The various considerations of UF and RO plants can be viewed at the following levels: (i) the local level of specific processes-considering economic, chemical, physical, microbial and membrane performance aspects [33], and (ii) at the regional level, having the complete picture of the water sources, supply and demand features and membrane characteristics [30]. At this level, UF and RO membrane performance is only one link in a multi-component system. Extra aspects to be considered also include feed water quality, environmental considerations for the disposal (or reuse) of concentrates, regulating issues and related risks [34].

Intangible benefits and disadvantages of MF, UF and RO pilot membrane plants are those features that are difficult to quantify by monetary cost evaluation. However, they are relevant to the potential user decision. Although they are difficult (or impossible) to quantify, the intangible benefits and/or disadvantages of a technology can outweigh the results of the tangible cost evaluation, thus affecting the go/no-go decision of potential end users. For example, potential users may find it beneficial to implement membrane technology (considering increased plant safety, reduced future liability, promotion of positive public awareness, etc.), even if it is more costly than the baseline technology.

In general, investment costs for a new treatment plant can be assessed as a function of a similar process for known capacity characteristics and given infrastructure Capacity $\mathrm{P}_{1}$ (e.g., volume, area, required energy and flow rates) and given cost $\left(\operatorname{CostP}_{1}, \$ / \mathrm{m}^{3}\right)$ and a scale-up factor $n_{P}$ :

$$
\operatorname{CostP}_{2}=\mathrm{KP} \times \operatorname{CostP}_{1} \times\left(\text { Capacity }_{2} / \text { Capacity }_{1}\right)^{\mathrm{n}_{\mathrm{P}}}
$$


where KP is a typical coefficient, $\operatorname{CostP}_{2}\left(\$ / \mathrm{m}^{3}\right)$ is the infrastructure cost for the new planet with Capacity $\mathrm{P}_{2}$. The exponent $\mathrm{n}_{\mathrm{P}}$ is a parameter representing the economy of scale associated with the infrastructure cost components. The process capacity is typically chosen to be a relevant and easy measurable plant characteristic. Depending on the process unit, the range of $\mathrm{n}$ is between 0.25 and 1.0 [34]. The $\mathrm{CostE}_{2}$ expressing for non-membrane equipment and facilities can be expressed similarly as power law expressions, correlating the equipment cost to the membrane surface area requirement, and implementing a generic form [35]:

$$
\mathrm{CostE}_{2}=\mathrm{KE} \times \operatorname{CostE_{1}} \times\left(\mathrm{AmmE}_{2} / \mathrm{AmmE}_{1}\right)^{\mathrm{n}_{\mathrm{E}}}
$$

where $\mathrm{KE}$ is a typical coefficient, $\operatorname{CostE}_{2}$ and $\operatorname{CostE}_{1}$ are the new and given costs respectively, for equipment depending on the surface area of the new and given membrane surface areas $\mathrm{AmmE}_{2}$ and AmmE $_{1}$ respectively, and a scaling-up factor $n_{E}$. correlation analysis, including data from various sources allows obtaining values for the different parameters [36]. The cost analysis is based on data from February 2010. However, there are negligible differences between current (February 2012) and February 2010 currency exchange rates vs. the New Israeli Shekel (NIS). During February 2010 the US Dollar/NIS exchange rate was 1/(3.77); the EURO/NIS exchange rate was 1/4.89. In February 2012 the exchange rates were US Dollar/NIS 1/(3.75) and EURO/NIS 1/(4.92), respectively.

Membrane pretreatment and treatment costs consist of capital investments, assessment of operational and maintenance expenses (O\&M: labor, energy, chemicals), wastewater quality monitoring and control. The O\&M costs are added to an annualized capital investment term to obtain a total annualized cost of current reclamation technology:

$$
\text { Total Annual Cost }=(\text { Total Annual Capital Costs })+(\text { Total Annual O\&M Expenses })
$$

However, when using mainly published data, investment costs are difficult to calculate accurately. Cost functions are commonly developed at a given time point for a specific organization, region or country, related to a specific wastewater system and estimated risks. Moreover, it is difficult to compare various scenarios mined from different sources, as the description of the components taken into account is often fuzzy. Finally, an indication of the accuracy obtained using published data is rarely provided. Consequently, cost analysis in the early phase of a project (without the performance of a pilot plant) requires the development of a specific cost function, which assumes that accurate and reliable estimations can be obtained.

Several deviations in performing a cost-effective analysis are common: (i) lack of reliable design data; (ii) construction periods are not harmonized; (iii) limited design alternatives; (iv) poorly designed pre-treatment; (v) limited data referring to the particular site; (vi) limited similar design projects based on extensive company experience, and (vii) very limited use of independent consultants for early performance analysis.

\subsection{The UF Objective Function and Constraints}

Current components of the UF objective function include selection of the pretreatment method and membrane type, pretreatment costs and UF operation expenses, which are necessary to attain a definite permeate quality, transportation of the brine, its disposal, permeate storage costs, general operation and maintenance expenses, design and contingency expenses. The primary operating component in the 
objective function to be considered in selection of the membrane type is UF permeate flux and the level of chemical cleaning, back-washing and maintenance. The objective (cost) function is given by the following expression:

$$
\left(\begin{array}{c}
\text { UF } \\
\text { Optimal } \\
\text { Cost }
\end{array}\right)=\left(\begin{array}{c}
\text { Effluent } \\
\text { Water } \\
\text { Cost }
\end{array}\right)+\left(\begin{array}{c}
\text { UF } \\
\text { Pr etreatment } \\
\text { Cost }
\end{array}\right)+\left(\begin{array}{c}
\text { UF } \\
\text { Unit } \\
\text { Cost }
\end{array}\right)+\left(\begin{array}{c}
\text { UF } \\
\text { O \& M } \\
\text { Expenses }
\end{array}\right)+\left(\begin{array}{c}
\text { Brine } \\
\text { Disposal } \\
\text { Cost }
\end{array}\right)-\left(\begin{array}{c}
\text { Re turn } \\
\text { for UF } \\
\text { Permeate }
\end{array}\right)
$$

where the following are assumed:

(a) Selection of the pretreatment method and membrane type takes into account the designed plant capacity, permeate salinity and experimental results obtained from pilot scale plants. Commonly, selection of the treatment method, and successively the membrane type, is associated with defining of a set of Boolean variables namely, receiving 0 or 1 value only.

(b) The feasibility analysis is based on capital and O\&M costs with a plant capacity of $20,000 \mathrm{~m}^{3} / \mathrm{d}, 95 \%$ recovery, and a flux of $27 \mathrm{Liter} /\left(\mathrm{m}^{2} \cdot \mathrm{hr}\right)$.

(c) Effluent water cost depends on a series of factors and the expenses for a specific site are given by a constant.

(d) There is no charge for UF retentate treatment - it is released back into the main effluent source and subsequently reused for another successive UF effluent feed cycle.

(e) There is no premium credited for the UF permeate quality.

The constraints define a feasible domain in the decision space. The constraints refer to the capacity of the system (both storage and flow rates), regime of applied reagents, minimum brine flow and maximum membrane feed flow. Every constraint which can be formulated as a function with the optimization variables can be incorporated into the management model (for example, the content of TSS in the UF permeate). The predominant constraints refer to UF permeate quality, restrictions placed on the pretreatment control, membrane performance, brine removal, environmental features, health restraining criteria, water demand and supply, and the plant layout. Additional constraints refer to energy requirements and losses, costs, budgetary limitation, labor availability and demand, land availability and potential demand for the permeate. Sets of constraints referring to pollution and health control depend on a series of factors. These factors include, among others, the chance of membrane failures and precautions normally taken. The constraints obtained are therefore of the general form:

Fr (various UF membrane blocking control factors, flow rates and energy losses) $<\operatorname{Pr}$

where $\operatorname{Fr}(\ldots$.$) is a general mathematical function expressing approval level of membrane performance$ integrity, and Pr expresses the statistical probability of related phenomena subject to operational conditions. The mixture of different mathematical terms, including probabilities, might turn the problem into a complex one for solution.

\subsection{The RO Objective Function and Constraints}

The RO component is an integrative part of the hybrid membrane systems which is utilized for polishing of the secondary effluent for unrestricted use. Similar to the UF component, modeling the RO part is based on defining an objective function (normally an expression referring to treated water costs) to be optimized, subject to a series of technological, environmental, chemical, microbial, 
physical and operational constraints. The components of the $\mathrm{RO}$ objective function include feed effluent cost (permeate of the UF stage), RO membrane type, RO operating costs necessary to attain a definite permeate quality, brine disposal design and contingency expenses. The primary benefit component in the objective function to be considered in selection of the RO membrane type is feed pressure, flux and permeate low salinity for dilution options with UF permeate and effluent. The RO objective (cost) function is given by the following general expression [Equation (6)]:

$$
\left(\begin{array}{c}
\text { RO } \\
\text { Optimal } \\
\text { Cost }
\end{array}\right)=\left(\begin{array}{c}
\text { Feed } \\
\text { Water } \\
\text { Cost }
\end{array}\right)+\left(\begin{array}{c}
\text { RO } \\
\text { Pr etreatment } \\
\text { Cost }
\end{array}\right)+\left(\begin{array}{c}
\text { RO } \\
\text { Unit } \\
\text { Cost }
\end{array}\right)+\left(\begin{array}{c}
\text { RO } \\
\text { O\& } \& \\
\text { Expenses }
\end{array}\right)+\left(\begin{array}{c}
\text { Brine } \\
\text { Disposal } \\
\text { Cost }
\end{array}\right)-\left(\begin{array}{c}
\text { Return } \\
\text { for RO } \\
\text { Permeate }
\end{array}\right)
$$

Selection of the RO pretreatment method and membrane type takes into account the designed plant capacity, permeate quality and experimental results from pilot plants, and is associated with defining of a set of Boolean variables, receiving 0.1 values only. The RO feasibility analysis is based on capital investments and operations \& maintenance expenses with a plant capacity of $6700 \mathrm{~m}^{3} / \mathrm{d}$, five different recoveries and seven different RO membranes. RO performance is based on field experience and criteria provided by related software (ImsDesign). Feed water cost is a function of UF pretreatment and chloride concentration and the expenses for a specific site are given by a constant. A premium is credited for the permeate quality: for every $100 \mathrm{mg} / \mathrm{L}$ TDS below the concentration of $400 \mathrm{mg} / \mathrm{L}$, a return of 0.25 US cents per $\mathrm{m}^{3}$ is paid. Brine disposal is based on disposal into the ocean.

\subsection{Formulation of the Optimization Model}

Estimating costs for water treatment facility projects require experience, engineering judgment and, to some extent, educated guesses based on familiarity with the project. Reliable construction, operations and maintenance cost data referring to a specific water and wastewater treatment project are essential for planning, design, and construction. All the costs excluding land, legal and fiscal considerations and peak power requirement are required. These parameters are based on data obtained during testing of the pilot plant at Kibbutz Chafets-Chaim (Israel). A general expression for this component $\left(\mathrm{Ct}_{\mathrm{m}}\right)$ for the $\mathrm{m}(\mathrm{m}=1, \ldots, \mathrm{M})$ treatment method is given by [30]:

$$
\mathrm{Ct}_{\mathrm{m}}=\mathrm{Cc}_{\mathrm{m}}(\mathrm{q})^{\alpha}+\mathrm{Co}_{\mathrm{m}}(\mathrm{q})^{\beta}+\mathrm{B}_{\mathrm{m}}
$$

where $\mathrm{Ct}_{\mathrm{m}}$ represents membrane pretreatment and treatment costs in US $\$$ per year; $\mathrm{Cc}_{\mathrm{m}}$ is cost coefficient for the capital investment in US $\$$ per year; $\mathrm{Co}_{\mathrm{m}}$ is cost coefficient for operation and maintenance expenses in US $\$$ per year; $\alpha$ and $\beta$ are exponents referring to the specific treatment method, $B_{m}$ is a constant referring to the $\mathrm{m}$ treatment method in US \$ per year; and $\mathrm{q}$ is the mean daily feed flow, $\mathrm{m}^{3} /$ day.

There are several estimations for the $\alpha$ exponent value for pumps: $\alpha=0.71$ for MSF (Multi-Stage Flash) desalination pumps [37] and $\alpha=0.79$ for RO pumps [37,38]. Non-membrane components have been scaled for total capital cost: (for MF, UF and NF plant) $\alpha=0.74$ [39], $\alpha=0.60$ and $\alpha=0.85$ (for brackish RO) [40]. The following correlations for different equipment items with UF technology were found: $\alpha=0.42$ for pipes and valves, $\alpha=0.66$ for instruments and control, $\alpha=0.53$ for tanks and frames, $\alpha=0.57$ for miscellaneous [35], and $\alpha=0.3$ for feed and circulation facility [39]. 
Expressions for the O\&M expenses (including the computations for $\beta$ ) are also given in the literature [41]. The relationships found apply to average performance of a plant and are often subject to high uncertainty unless very similar configurations are considered. In order to take into account pilot plant performance for assessing operating costs, deductive models may be inserted, based on engineering calculations $[42,43]$. The assessment of variable operating costs on the basis of simulation variables and parameters requires a number of hypotheses (e.g., head losses, flux decline). The expenses for the energy $\mathrm{Cg}_{\mathrm{m}}$ (US \$ per year) for operating the various components can be assessed by [30]:

$$
\mathrm{Cg}_{\mathrm{m}}=\mathrm{C}_{\mathrm{e}} \cdot \mathrm{E} \cdot \mathrm{T}_{\mathrm{y}} \cdot(\mathrm{q})^{\delta}
$$

where $\mathrm{C}_{\mathrm{e}}$ is a unit cost for energy in US \$ per KWhr; $\mathrm{E}$ is the specific energy required per capita- $\mathrm{a}$ perceptive value is $0.0026 \mathrm{KWhr} /$ capita per year; $\mathrm{T}_{\mathbf{y}}$ is annual operation duration (hours) and a reasonable value is 8000 hours/year and $\boldsymbol{\delta}$ is an energy cost exponent. The expenses for energy also include pumping requirements. The general expression for this component is given by:

$$
\mathrm{C}_{\mathrm{ue}}=0.276 \mathrm{C}_{\mathrm{e}} \cdot \mathrm{Q}_{\mathrm{h}} \cdot \mathrm{H} \cdot \mathrm{T}_{\mathrm{y}} / \eta
$$

where $Q_{h}$ is the pump flow, $\mathrm{m}^{3} / \mathrm{h} ; \mathrm{H}$ is the pressure head required at the pump inlet, $\mathrm{m} ; \mathrm{T}_{\mathrm{y}}$ is operating duration (hours) per year; $\eta$ is the pump efficiency, expressed as a percentage. All annual expenses $\left(\mathrm{C}_{\mathrm{an}}\right)$ for any capital investments (feed, pretreatment, UF, RO, post treatment and brine removal) are assessed by using the Capital Recovery Factor (CRF) and actual investment $\left(\mathrm{C}_{\mathrm{ac}}\right)$ [35]:

$$
\mathrm{C}_{\mathrm{an}}=\left\{\mathrm{i} /\left[1-(1+\mathrm{i})^{-\mathrm{n}}\right]\right\} \cdot \mathrm{C}_{\mathrm{ac}}
$$

where $\mathrm{i}$ is the interest rate (fractional value) and $\mathrm{n}$ is the life span, in years.

$$
\mathrm{C}_{\mathrm{an}}=\mathrm{CRF} \cdot \mathrm{C}_{\mathrm{ac}}
$$

Annual expenses for membrane investment $\left(\mathrm{C}_{\mathrm{anm}}\right)$ are assessed by using the actual investment $\left(\mathrm{C}_{\mathrm{acm}}\right)$ and the following expression [36]:

$$
\mathrm{C}_{\mathrm{anm}}=\left\{\mathrm{i} /\left[(1+\mathrm{i})^{\mathrm{n}}-1\right]\right\} \cdot \mathrm{C}_{\mathrm{acm}}
$$

All maintenance expenses $C_{\text {po }}$ (US $\$$ per year) can be assessed on the basis of the capital investment:

$$
\mathrm{C}_{\mathrm{po}}=\phi_{\mathrm{p}} \cdot \mathrm{C}_{\mathrm{pt}}
$$

where $\phi_{\mathrm{p}}$ is a fraction (commonly $0.05<\phi_{\mathrm{p}}<0.30$ ) representing the percentage of the capital annual $\operatorname{cost} \mathrm{C}_{\mathrm{pt}}$ (US $\$$ per year) which is considered for operation and maintenance expenses. The life span of the system components are: 10 years for water pretreatment and control segment; 15 years for pumps, electrical equipment and service roads; 25 years for the reservoir; 30 years for pipes and 40 years for buildings. Operation and maintenance (O\&M) expenses are assessed as percentages of the capital investment (e.g., $0.5 \%$ of the investment for reservoirs and buildings, $1 \%$ of the investment for pipes and roads; $4 \%$ of the investment for accessories, electrical engines and pumps; $5 \%$ of the investment for water treatment equipment). The interest rate is $3.5 \%$. The feed effluent cost is $15 \mathrm{US}$ cent $/ \mathrm{m}^{3}$ [22], and the energy cost is 0.062 US $\$ / \mathrm{kWhr}$.

The return for permeate depends on the purpose of application and related economical aspects. Irrigation is the main course of effluent reuse-a premium is credited for the permeate quality. Main 
constituents for UF performance control to be examined include $\mathrm{BOD}_{5}, \mathrm{COD}$, TSS and pathogenic indicators. The main constituents for RO performance include salt content and $\mathrm{pH}$.

Finally, when comparing different alternatives, special attention should be focused on the chosen time and space scales, as they may influence the options of new technology implementation and cost function [40]. It is advantageous to consider an overall plant evaluation over the life span of the plant.

\section{A Case Study}

\subsection{Effluent Quality and Membrane Performance}

Field experiments were conducted in the agricultural fields of Kibbutz (combinative farm) Chafets-Chaim, located $40 \mathrm{~km}$ west of Jerusalem, Israel. Mean annual precipitation in the command region is around $550 \mathrm{~mm}$ from October to March. The mean minimal ambient temperature is around $8{ }^{\circ} \mathrm{C}$ during January and $17{ }^{\circ} \mathrm{C}$ during August. Mean maximal temperature reaches $20{ }^{\circ} \mathrm{C}$ during January and $31^{\circ} \mathrm{C}$ during August. Maximal evaporation from Class " $\mathrm{A}$ " Pan is around $8 \mathrm{~mm} /$ day. Most applied effluent is obtained from a series of effluent storage reservoirs. This effluent was also used in the integrative pilot system (Table 4).

Table 4. Quality of the effluent treated in the integrative membrane system $(\mathrm{mg} / \mathrm{L})$, Chafets-Chaim, 2000 [33].

\begin{tabular}{|c|c|c|c|c|c|c|c|c|}
\hline \multirow{2}{*}{$\begin{array}{c}\text { Quality } \\
\text { Parameter }\end{array}$} & \multicolumn{8}{|c|}{ Date, Summer 2000} \\
\hline & $\begin{array}{c}\text { May } \\
\mathbf{3} \\
\end{array}$ & $\begin{array}{c}\text { May } \\
23 \\
\end{array}$ & $\begin{array}{c}\text { June } \\
5 \\
\end{array}$ & $\begin{array}{c}\text { June } \\
26 \\
\end{array}$ & $\begin{array}{c}\text { August } \\
16 \\
\end{array}$ & $\begin{array}{c}\text { August } \\
23 \\
\end{array}$ & $\begin{array}{c}\text { August } \\
\mathbf{3 0} \\
\end{array}$ & $\begin{array}{c}\text { September } \\
21 \\
\end{array}$ \\
\hline pH (-) & 8.15 & 8.11 & 7.92 & 7.74 & 7.98 & 7.57 & 7.60 & 7.89 \\
\hline $\mathrm{pH}_{\mathrm{adj}} *(-)$ & 7.51 & 7.48 & 7.42 & 7.54 & 7.56 & 7.21 & 7.22 & 7.34 \\
\hline $\mathrm{EC}, \mathrm{dS} / \mathrm{m}$ & 1.81 & 1.94 & 2.06 & 1.82 & 2.32 & 2.33 & 2.34 & 2.42 \\
\hline TSS & 31 & 52 & 42 & 22 & 75 & 45 & 45 & 63 \\
\hline $\mathrm{COD}_{\text {total }}$ & 100 & 95.8 & 360 & 59.6 & 289 & 289 & 222 & 189 \\
\hline $\mathrm{COD}_{\text {filtered }}$ & 60 & 65.2 & 180 & 30 & 118 & 118 & 158 & 69 \\
\hline $\mathrm{BOD}_{\text {total }}$ & 13.2 & 12.0 & 13.2 & 3.0 & 33.0 & 33.0 & 36.0 & 30.8 \\
\hline $\mathrm{BOD}_{\text {filtered }}$ & 3.6 & 7.8 & 6.1 & 2.4 & 14.0 & 14.0 & 14.0 & 15.0 \\
\hline $\mathrm{N}-\mathrm{NH}_{4}^{+}$ & 27.5 & 24.4 & 22.5 & 23.4 & 25.6 & 42.1 & 47.7 & 42.9 \\
\hline $\mathrm{NO}_{3}$ & 0.00 & 0.12 & 0.29 & 0.07 & 0.00 & 0.00 & 0.00 & 0.01 \\
\hline $\mathrm{NO}_{2}$ & 0.00 & 0.85 & 3.03 & 2.20 & 0.00 & 0.04 & 0.03 & 0.03 \\
\hline Alkalinity as $\mathrm{CaCO}_{3}$ & 420 & 395 & 435 & 440 & 510 & 470 & 485 & 495 \\
\hline $\mathrm{HCO}_{3}$ & 520 & 482 & 530 & 488 & 622 & 573 & 580 & 604 \\
\hline $\mathrm{Cl}$ & 350 & 368 & 410 & 347 & 399 & 374 & 385 & 383 \\
\hline $\mathrm{SO}_{4}$ & 50.8 & 67.9 & 67.1 & NM & NM & NM & NM & NM \\
\hline $\mathrm{PO}_{4}$ & 11.2 & 42.7 & 46.5 & 46.2 & 57.7 & 89.8 & 94.9 & $\mathrm{NM}$ \\
\hline $\mathrm{Na}$ & 240 & 270 & 280 & 212 & NM & NM & 265 & 229 \\
\hline K & 47 & 16.4 & 15.9 & 32 & NM & NM & 34 & 34 \\
\hline $\mathrm{Ca}$ & 76.1 & 65.1 & 92.0 & 73.4 & NM & NM & 64.0 & 66.7 \\
\hline $\mathrm{Mg}$ & 37.0 & 38.0 & 42.0 & 37.0 & NM & NM & 37.0 & 33.8 \\
\hline SAR ** & 8.08 & 9.52 & 9.38 & 7.10 & - & $-* * *$ & 11.85 & 9.51 \\
\hline $\operatorname{PAR} * *$ & 0.93 & 0.34 & 0.31 & 0.63 & - & - & 0.90 & 0.83 \\
\hline
\end{tabular}

* Adjusted value; ** Sodium absorption ratio and potassium absorption ratio, respectively; *** NM-Not monitored. 
The Integrative Membrane Pilot Unit (IMPU) consists of several components (Figure 1). These include a two-ring filter (100 and 20 microns respectively), a feeding pump, one membrane module with a single Spiral Wound (SW) UF membrane, an intermittent storage container for the UF permeate, two modules with four Spiral Wound (SW) RO membranes, a flushing system and a chemical cleaning unit at the entrance and an additional storage container for the high quality RO permeate applied for unrestricted irrigation. Data concerning the performance of the pilot plant can be found in the literature [33]. The characteristics of the membranes are given in Table 5.

Figure 1. Pilot plant layout for secondary effluent polishing.

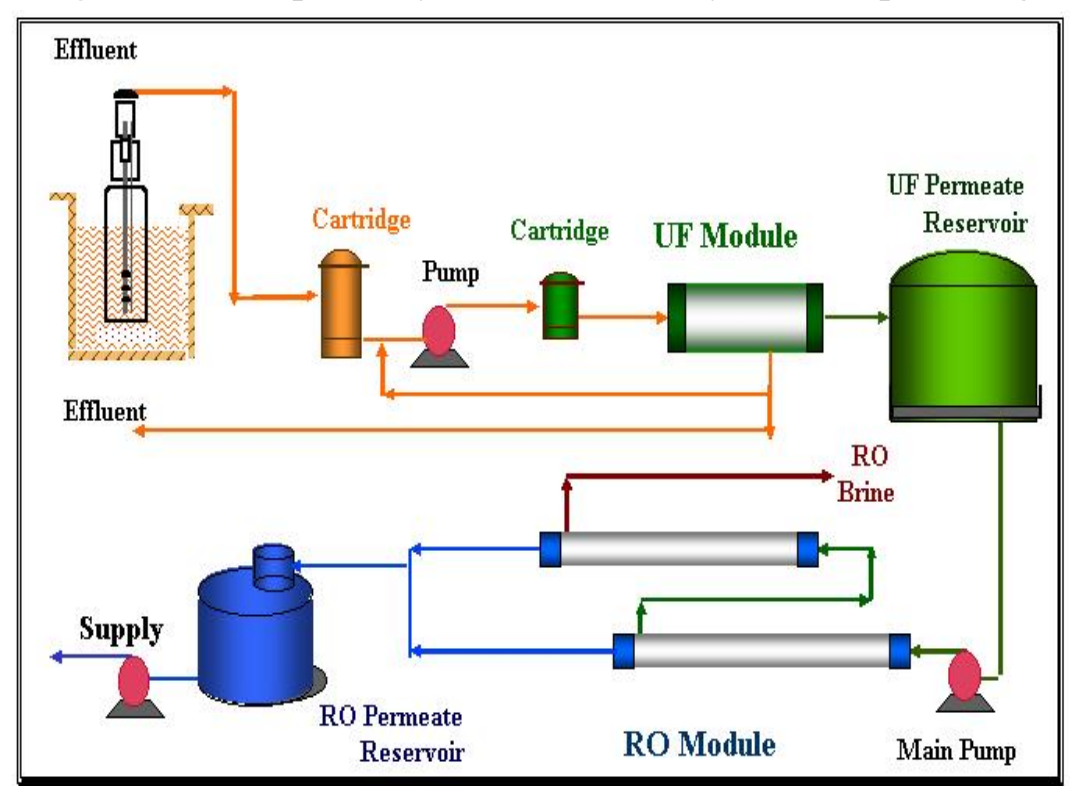

Table 5. Selected design and operating parameters for membrane plant cost estimates.

\begin{tabular}{lllcc}
\hline \multicolumn{1}{c}{ Subject } & \multicolumn{1}{c}{ Description } & \multicolumn{1}{c}{ Unit } & $\begin{array}{c}\text { UF } \\
\text { Spiral-Wound }\end{array}$ & $\begin{array}{c}\text { RO } \\
\text { Spiral-Wound }\end{array}$ \\
\hline Membrane & Membrane length & $\mathrm{mm}$ & 1,016 & 1,016 \\
data & Membrane diameter & $\mathrm{mm}$ & 200 & 200 \\
& Membrane life span & years & 5 & 5 \\
Module & Membrane active area & $\mathrm{m}^{2}$ & 37.1 & 37.1 \\
Cost & Element & number & 7 & 6 \\
& module & US \$ & 1,200 & 1,600 \\
Operating & Fembrane & US \$ & 450 & 450 \\
parameters & Feed pressure & Liter/m ${ }^{2}$-hour & 27 & 34 \\
& Recovery & bar & 4 & 12.5 \\
& Back-flush & \% & 95 & 80 \\
& Back-flush duration & seconds & $30-45$ & no \\
& Back-flush pressure & bar & 4 & no \\
& Back-flush frequency & Number/day & 48 & no \\
& Chemical cleaning frequency & Number/year & 48 & no \\
\hline
\end{tabular}

The feed water (secondary effluent) is taken directly from the 100-micron filter at Chafets-Chaim reservoir (volume of 3.5 million $\mathrm{m}^{3}$ secondary effluent). Table 6 presents typical water qualities of the 
pilot plant performance. UF treatment provided effective pretreatment for the RO unit. It should be noted that the UF membrane did not remove all organic compounds. On the other hand it appears to have acted as a disinfecting step by completely removing Fecal Coliforms.

Table 6. Pilot plant water quality parameters.

\begin{tabular}{|c|c|c|c|c|c|c|}
\hline \multirow[b]{2}{*}{ Parameters } & \multicolumn{5}{|c|}{ Selected recorded flow } & \multirow[b]{2}{*}{$\begin{array}{c}\text { Total } \\
\text { Rejection \%, } \\
\lambda^{\#}\end{array}$} \\
\hline & $\begin{array}{c}\text { Feed } \\
\text { Cfr }\end{array}$ & $\begin{array}{c}\text { UF } \\
\text { Permeate } \\
\text { Cpuf }\end{array}$ & $\begin{array}{c}\text { UF } \\
\text { Brine } \\
\text { Cbuf }\end{array}$ & $\begin{array}{c}\text { RO } \\
\text { Permeate } \\
\text { Cpro } \\
\end{array}$ & $\begin{array}{c}\text { RO } \\
\text { Brine } \\
\text { Cbro } \\
\end{array}$ & \\
\hline $\mathrm{pH}(-)$ & 8.48 & 8.2 & 8.3 & 7.3 & 8.2 & - \\
\hline $\mathrm{EC}, \mathrm{dS} / \mathrm{m}$ & 2.3 & 2.3 & 2.3 & 0.001 & 3.4 & 99 \\
\hline TSS, mg/L & 22 & 0 & 63 & 0 & 0 & 100 \\
\hline $\mathrm{BOD}_{5}, \mathrm{mg} / \mathrm{L}$ & 27 & 15 & 42 & 4 & 12 & 85 \\
\hline $\mathrm{COD}, \mathrm{mg} / \mathrm{L}$ & 180 & 24 & 600 & 0 & 100 & 100 \\
\hline $\mathrm{Cl}^{-}, \mathrm{mg} / \mathrm{L}$ & 370 & 370 & 370 & 8.5 & 910 & 98 \\
\hline $\mathrm{SO}_{4}{ }^{2-}, \mathrm{mg} / \mathrm{L}$ & 99.4 & 87 & 99 & 7.1 & 168 & 93 \\
\hline $\mathrm{HCO}_{3}{ }^{2-}, \mathrm{mg} / \mathrm{L}$ & 378 & 357 & 382 & 15 & 710 & 96 \\
\hline $\mathrm{NH}_{4}^{+}, \mathrm{mg} / \mathrm{L}$ & 5.6 & 5.6 & 5.6 & 0.3 & 12.7 & 95 \\
\hline $\mathrm{PO}_{4}{ }^{3-}, \mathrm{mg} / \mathrm{L}$ & 20.2 & 20.2 & 20.6 & 0.4 & 41.3 & 98 \\
\hline $\mathrm{Na}^{+}, \mathrm{mg} / \mathrm{L}$ & 275 & 275 & 350 & 12 & 605 & 96 \\
\hline $\mathrm{K}^{+}, \mathrm{mg} / \mathrm{L}$ & 32 & 32 & 39 & 1.4 & 58 & 96 \\
\hline $\mathrm{Ca}^{++}, \mathrm{mg} / \mathrm{L}$ & 35.3 & 28.9 & 35 & 1.2 & 63 & 97 \\
\hline $\mathrm{Mg}^{++}, \mathrm{mg} / \mathrm{L}$ & 42 & 42 & 42 & 0.7 & 75 & 98 \\
\hline Fecal Coliform, CFU/100 mL & 23,000 & 0 & 34,000 & 0 & 330 & 100 \\
\hline Coliphages F+, PFU/100 mL & 90 & 10 & 40 & 0 & 10 & 91 \\
\hline $\begin{array}{l}\text { Somatic Coliphages, } \\
\text { PFU/100mL }\end{array}$ & 3,800 & 50 & 3,400 & 20 & 280 & 99 \\
\hline
\end{tabular}

\# Equation (14).

Total rejection was calculated according to the following expression:

$$
\lambda_{\mathrm{i}}=100\left(\mathrm{Cfr}_{\mathrm{i}}-\mathrm{Cpro}_{\mathrm{i}}\right) / \mathrm{Cfr}_{\mathrm{i}}
$$

where,

$\lambda_{i}$ - the rejection of i parameter, $\%$

$\mathrm{Cfr}_{\mathrm{i}}$ - the feed concentration of $\mathrm{i}$ parameter, (concentration)

$\mathrm{Cpro}_{\mathrm{i}}$ - the RO permeate concentration of i parameter, (concentration).

The data recorded reveals that the UF membrane barrier guarantees over 4 log fecal coliform removal. The tests concerning Somatic Coliphages and $\mathrm{F}^{+}$Coliphages may indicate the presence of bacteria colonies on the membrane surface that can be removed by a sodium hydroxide solution in order to prevent bacterial re-growth. The RO permeate quality was fairly constant and the ionic removal range was 93 to 98 percent: a superior quality relative to agricultural irrigation regulations. Odors were detected in the RO permeate and it is speculated that it indicated the presence of $\mathrm{H}_{2} \mathrm{~S}$ compounds. Figure 2 presents the normalized UF permeate flux change in time during the first $100 \mathrm{~h}$ 
of operation. After 67 operating hours the membranes lost about 35 percent of their permeate flow rate because system recovery was too high. However, citric acid cleaning recovered the system performance.

Figure 2. Normalized UF permeate flow relative to start up.

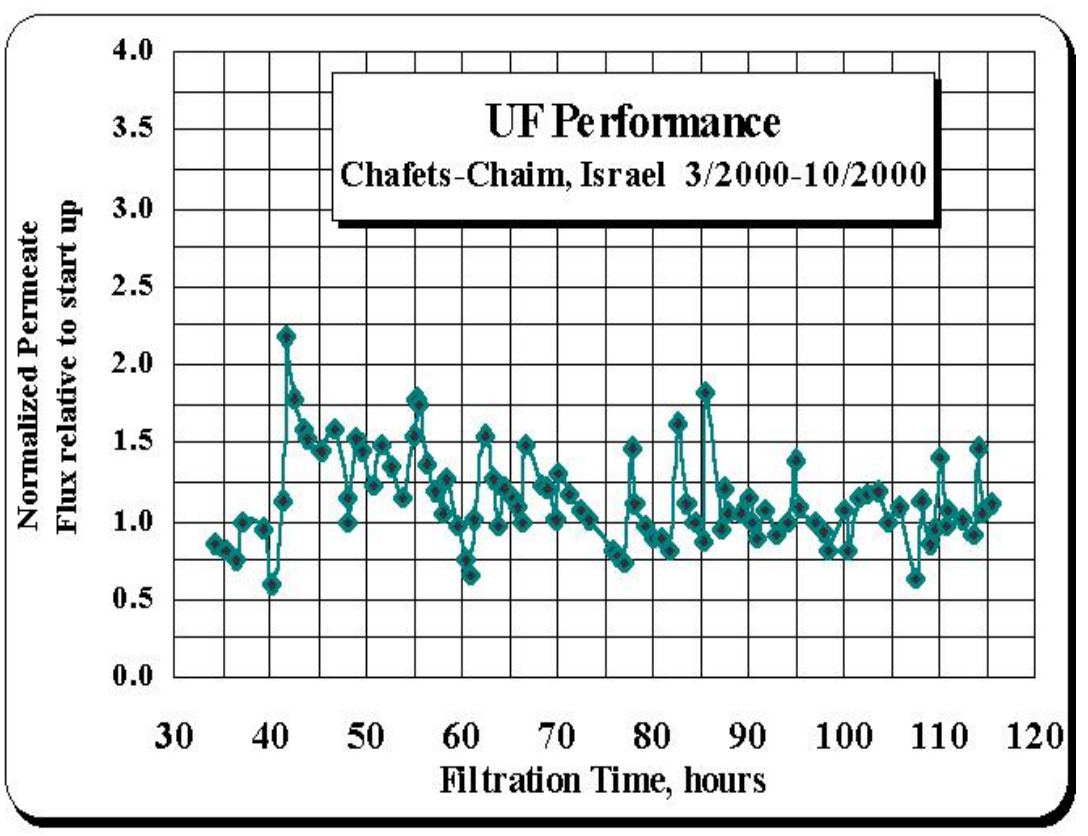

\subsection{Agricultural Yields}

The treated membrane effluent was used for irrigation of an experimental plot located in a commercial pepper field. The pepper yield was assessed by taking three samples of each treatment in an area of $2 \mathrm{~m}^{2}$ (Table 7). These preliminary results indicate the trend of leaching process effects attained during irrigation by blending RO permeate and conventional secondary effluent. A relatively low salinity was identified in the active root zone. The yield with the RO permeate, intermittently applied with the secondary conventional effluent, is higher by more than $100 \%$ relative to applying secondary effluent only. The higher yield obtained for the intermittent secondary effluent and RO effluent application, even under Onsurface Drip Irrigation (ODI), demonstrated the impact of the contribution of effluent quality that contains reduced amounts of dissolved solids.

Table 7. Red pepper yield under various effluent qualities and application methods.

\begin{tabular}{lc}
\hline \multicolumn{1}{c}{ Effluent quality and application method } & Yield, Kg/ha \\
\hline Secondary effluent under Onsurface Drip Irrigation (ODI) & 9,600 \\
Secondary effluent under Subsurface Drip Irrigation (SDI) & 14,000 \\
Secondary effluent intermittently applied with RO permeate under ODI & 19,000 \\
\hline
\end{tabular}

\subsection{Costs of UF Membrane Performance}

A preliminary economic assessment of the UF component performance is presented in Figure 3. The linear model was tested for a series of reasonable conditions. The dependent variable is the flux which encompasses a series of input parameters. As indicated, there is, subject to a series of local conditions, a range which allows obtaining minimal costs per one UF treated $\mathrm{m}^{3}$ of effluent. In this 
case the preferable flux is in the range of $25 \mathrm{~L} /\left(\mathrm{m}^{2} \cdot \mathrm{hr}\right)$ to $30 \mathrm{~L} /\left(\mathrm{m}^{2} \cdot \mathrm{hr}\right)$. Further field studies and management modeling are in progress to verify these findings. Running the management optimization model yielded extra polishing costs in the UF stage in the range of US $\$ 0.10 / \mathrm{m}^{3}$ to US $\$ 0.15 / \mathrm{m}^{3}$.

Figure 3. The extra UF cost for a treatment plant with a capacity of $20,000 \mathrm{~m}^{3} /$ day.

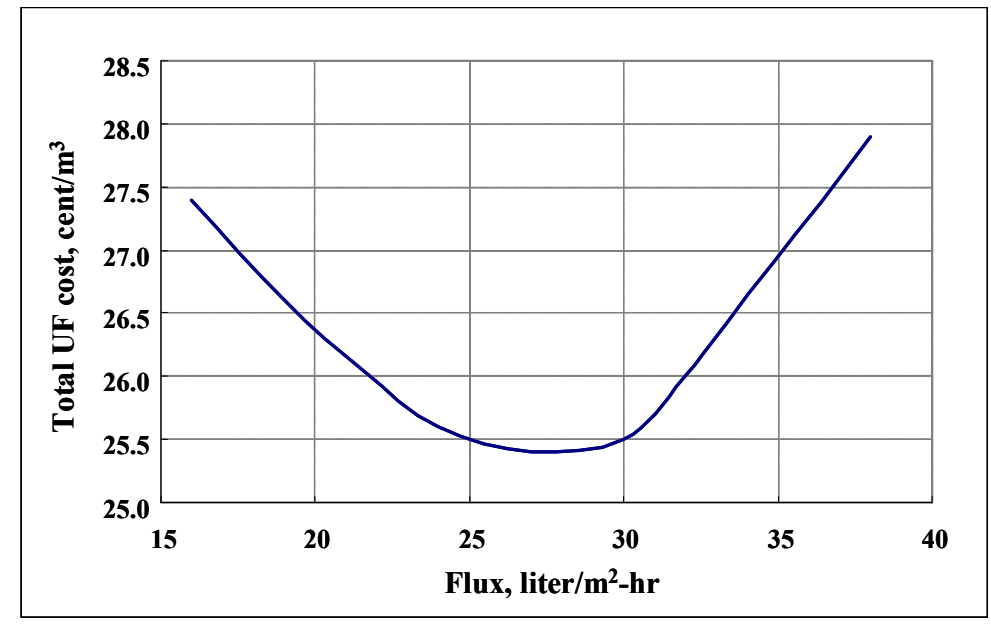

\section{Conclusions and Outlooks}

Bridging between supply and demand for water, primarily in water-scarce regions, can be alleviated by intense utilization of treated domestic wastewater. However, the salinity of the applied secondary effluent can frequently have diverse effects on the soils' fertility, groundwater quality and on the agricultural yields. The problem of excess dissolved solids content in the applied effluent can be solved by combining various membrane treatment technologies and subject to economic, environmental, production and public acceptance considerations. The combined theoretical and field work efforts show that hybrid membrane systems, consisting of UF membranes and in series RO membrane generate promising agricultural yields, along with minimal environmental pollution risks. The integrative approach of producing the extra high quality waters is feasible since it is based on combining chemicals, microbiological agents, treatment technologies, materials characteristics, environment management, public perception, economics, and marketing. Running the management optimization model yielded extra UF permeate costs of up to US $\$ 0.15 / \mathrm{m}^{3}$.

\section{Acknowledgments}

The work was partially supported by The IWRM (Integrated Water Resource Management) - SMART (Sustainable Management of Available Water Resources with Innovative Technologies) project on development, modeling and providing tools for optimal water use in arid regions, which is supported by The Federal Ministry of Education and Research, Germany and The Ministry of Science and Technology (MOST) of the State of Israel.

The authors are indebted to the anonymous referees for their contributive comments. 


\section{References}

1. Palese, A.M.; Pasquale, V.; Celano, G.; Figliuolo, G.; Masi, S.; Xiloyannis, C. Irrigation of olive groves in Southern Italy with treated municipal wastewater: Effects on microbiological quality of soil and fruits. Agric. Ecosyst. Environ. 2009, 129, 43-51.

2. Brimberg, J.; Oron, G.; Mehrez A. An operational model for utilizing water resources of varying qualities in an agricultural enterprise. Geogr. Res. Forum 1997, 29, 67-77.

3. Yang, F.; Wang, Y.; Bick, A.; Brenner, A.; Ben-David, E.; Oron, G. A long-term application of a pilot airlift membrane bioreactor for domestic wastewater treatment. Desalination Water Treat. 2009, 4, 212-217.

4. Oron, G.; Gillerman, L.; Lal, A.; Manor, Y.; Braude, E.; Bick, A. Minimizing health risks during secondary effluent application via subsurface drip irrigation. Water Sci. Technol. 2010, 62, 2330-2337.

5. Ustun, G.E.; Kutlu, S.; Solmaz, A.; Ciner, F.; Baskaya, H.S. Tertiary treatment of a secondary effluent by the coupling of coagulation-flocculation-disinfection for irrigation. Desalination 2011, 277, 207-212.

6. Oron, G.; Gillerman, L.; Bick, A.; Manor, Y.; Buriakovsky, N.; Hagin, J. Membrane technology for sustainable treated wastewater reuse: Agricultural; environmental and hydrological considerations. Water Sci. Technol. 2008, 57, 1383-1388.

7. Bick, A.; Plazas, J.G.; Yang, F.; Hagin J.; Oron, G. Immersed Membrane BioReactor (IMBR) for treatment of combined domestic and dairy wastewater in an isolated farm: An exploratory case study implementing the Facet Analysis (FA). Desalination 2009, 249, 1217-1222.

8. Drioli, E.; Stankiewicz, A.I.; Macedonio, F. Membrane engineering in process intensification-An overview. J. Membr. Sci. 2011, 380, 1-8.

9. Zheng, L.; Huaqiang, C.; Bingzhi, D.; Hao, L. Characterization of natural organic foulants removed by microfiltration. Desalination 2011, 277, 370-376.

10. Lee, J.; Walker, H.W. Mechanisms and factors influencing the removal of microcystin-LR by ultrafiltration membranes. J. Membr. Sci. 2008, 320, 240-247.

11. Durham, B.; Bourbigot, M.M.; Pankratz, T. Membranes as pretreatment to desalination in wastewater reuse: Operating experience in the municipal and industrial sectors. Desalination 2001, 138, 83-90.

12. Won, W.; Shields, P. Comparative life cycle costs for operation of full-scale conventional pretreatment/RO and MF/RO systems. In Proceedings of the AWWA Membrane Technology Conference, Long Beach, CA, USA, 28 February-3 March 1999.

13. Pankratz, T.; Durham, B. Dual-membrane desalination helps take the "waste" out of “wastewater". Int. Desalination Water Reuse 2001, 11, 32-38.

14. Ordóñez, R.; Hermosilla, D.; San Pío, I.; Blanco, A. Evaluation of MF and UF as pretreatments prior to RO applied to reclaim municipal wastewater for freshwater substitution in a paper mill: A practical experience. Chem. Eng. J. 2011, 166, 88-98.

15. Guo, H.; Wyart, Y.; Perot, J.; Nauleau, F.; Moulin, P. Low-pressure membrane integrity tests for drinking water treatment: A review. Water Res. 2010, 44, 41-57. 
16. Kappelhof, J.W.; Vrouwenvelder, N.M.H.S.; Schaap, M.;. Kruithof, J.C.; van der Kooij, D.; Schippers, J.C. An in situ biofouling monitor for membrane systems. Water Supply 2003, 3, 205-210.

17. Vrouwenvelder; J.S.; van Paassen, J.A.M.; Wessels, L.P.; van Dam, A.F.; Bakker, S.M. The membrane fouling simulator: A practical tool for fouling prediction and control. J. Membr. Sci. 2006, 281, 316-324.

18. Calleja, I.; Delgado, L. European environmental technologies action plan (ETAP). J. Clean. Prod. 2008, 16, 181-183.

19. Halperin, R. Irrigation with Effluents Standards; The State of Israel, Israeli ministry of Health: Jerusalem, Israel, 1999.

20. Verlicchi, P.; Galletti, A.; Masotti, L. A promising practice to reclaim treated wastewater for reuse: Chemical disinfection followed by natural systems. Desalination 2009, 247, 490-508.

21. Hornstra; L.M.; Smeets, P.W.M.H.; Medema, G.J. Inactivation of bacteriophage MS2 upon exposure to very low concentrations of chlorine dioxide. Water Res. 2011, 45, 1847-1855.

22. Yaron, D.; Ravina, I.; Efrat, R.; Oron, G.; DeMalach, Y.; Hadas, A.; Hamberg, D.; Haruvi, N.; Mishaeli, D.; Frenkel, C. The final report of the committee on "Irrigation with effluent in Agriculture" [Hebrew]; Report to the Water Commissioner; The Ministry of National Infrastructure: Tel-Aviv, Israel, 1999.

23. Harussi, Y.; Rom, D.; Galil, N.; Semiat, R. Evaluation of membrane processes to reduce the salinity of reclaimed wastewater. Desalination 2001, 137, 71-89.

24. Ayers, R. S.; Westcot, D. W. Water Quality for Agriculture. Food and Agricultural Organization (FAO) of the United Nations; FAO Irrigation and Drainage Paper 29; FAO: Rome, Italy, 1985.

25. James, D.; Hanks, D.; Jurinak, J. Modern Irrigated Soils; John Wiley and Sons: New York, NY, USA, 1982.

26. Leeden, V. L.; Troise, F. L.; Todd, D. K. The Water Encyclopedia, 2nd ed.; Lewis Publishers: Boca Raton, FL, USA, 1990.

27. Morales-Garcia, D.; Stewart, K. A.; Seguin, P.; Madramootoo, C. Supplemental saline drip irrigation applied at different growth stages of two bell pepper cultivars grown with or without mulch in non-saline soil. Agric. Water Manag. 2011, 98, 893-898.

28. Akponikpè, P.B.I.; Wima, K.; Yacouba, H.; Mermoud, A. Reuse of domestic wastewater treated in macrophyte ponds to irrigate tomato and eggplant in semi-arid West-Africa: Benefits and risks. Agric. Water Manag. 2011, 98, 834-840.

29. Bick, A.; Oron, G. Desalination technology for optimal renovation of saline groundwater in a natural reservoir. Desalination 2000, 131, 97-104.

30. Oron, G. Management modeling of integrative wastewater treatment and reuse systems. Water Sci. Technol. 1996, 33, 95-105.

31. Persia, C.; Oron, G.; Mehrez, A. Optimal operation of regional system with diverse water quality resources. J. Water Resour. Plan. Manag. 1997, 34, 243-252.

32. Nnane, D.E.; Ebdon, J.E.; Taylor, H.D. Integrated analysis of water quality parameters for cost-effective faecal pollution management in river catchments. Water Res. 2011, 45, 2235-2246. 
33. Bick; A.; Gillerman, L.; Shatz, T.; Dagan, M.; Negrin, M.; Manor, Y.; Oron, G. Membrane technology for effective irrigation with secondary effluent. Int. Water Irrig. 2001, 21, 34-42.

34. Wright, D.G.; Woods, D.R. Evaluation of capital cost data, Part 8: Liquid waste disposal with emphasis on biological treatment. Can. J. Chem. Eng. 1994, 72, 342-351.

35. Sethi, S.; Wiesner. M.R. Simulated cost comparisons of hollow-fiber and integrated nanofiltration configurations. Water Res. 2001, 34, 2589-2597.

36. Turkay, M.; Grossmann, I.E. Structural flowsheet optimization with complex investment cost functions. Comput. Chem. Eng. 1998, 22, 673-686.

37. Uche, J.; Serra, L.; Valero, A. Thermo economic optimization of a dual-purpose power and desalination plant. Desalination 2001, 136, 147-158.

38. Pickering, K.D.; Wiesner, M.R. Cost model for low pressure membrane filtration. J. Environ. Eng. 1993, 119, 772-797.

39. Dharmappa, H.B.; Hagare, P. Economic analysis and design of crossflow microfiltration for water treatment systems. Desalination 1999, 121, 1-11.

40. Georgopoulou, E.; Kotronarou, A.; Koussis, A.; Restrepo, P.J.; Gomez-Gotor, A.; Jimenez, J.J.R. A methodology to investigate brackish groundwater desalination coupled with aquifer recharge by treated wastewater as an alternative strategy for water supply in Mediterranean areas. Desalination 2001, 136, 307-315.

41. Vanrolleghem, P.A.; Jeppsson, U.; Carstensen, J.; Carlsson, B.; Olsson, G. Integration of wastewater treatment plant design and operation-A systematic approach using cost functions. Water Sci. Technol. 1996, 34, 159-171.

42. Balmér, P.; Mattson, B. Wastewater treatment plant operation costs. Water Sci. Technol. 1998, 30, 7-15.

43. Brett, S.W.; Morse, G.K.; Lester, J.N. Operational expenditure in the water industry (I): A methodology for estimating variable costs at an advanced water treatment works. Eur. Water Manag. 1998, 1, 31-38.

(C) 2012 by the authors; licensee MDPI, Basel, Switzerland. This article is an open access article distributed under the terms and conditions of the Creative Commons Attribution license (http://creativecommons.org/licenses/by/3.0/). 